\title{
Overlap between vulnerable top predators and fisheries in the Benguela upwelling system: implications for marine protected areas
}

\author{
L. Pichegru ${ }^{1,2, *}$, P. G. Ryan ${ }^{2}$, C. Le Bohec ${ }^{1}$, C. D. van der Lingen ${ }^{3,4}$, R. Navarro ${ }^{4,5}$, \\ S. Petersen ${ }^{2}$, S. Lewis ${ }^{6}$, J. van der Westhuizen ${ }^{3}$, D. Grémillet ${ }^{2,7}$ \\ ${ }^{1}$ Centre National de la Recherche Scientifique, Institut pluridisciplinaire Hubert Curien, Département Ecologie, \\ Physiologie et Ethologie, 23 rue Becquerel, 67087 Strasbourg cedex 2, France \\ ${ }^{2}$ DST/NRF Centre of Excellence at the Percy FitzPatrick Institute of African Ornithology, University of Cape Town, \\ Rondebosch 7701, South Africa \\ ${ }^{3}$ Marine and Coastal Management, Department of Environmental Affairs and Tourism, Private Bag X2, Rogge Bay 8012, \\ South Africa \\ ${ }^{4}$ Marine Research Institute, Zoology Department, University of Cape Town, South Africa \\ ${ }^{5}$ Animal Demography Unit, Department of Zoology, University of Cape Town, Rondebosch 7701, South Africa. \\ ${ }^{6}$ Institute of Evolutionary Biology, School of Biological Sciences, University of Edinburgh Ashworth Labs, \\ The King's Buildings, West Mains Road, Edinburgh EH9 3JT, UK \\ ${ }^{7}$ Centre National de la Recherche Scientifique, CEFE - UMR 5175, 1919 Route de Mende, 34293 Montpellier cedex 5, France
}

\begin{abstract}
Industrial-scale fisheries are often thought to reduce food availability for top predators. It is essential to estimate the spatial and temporal overlap over a fine scale between fisheries and predators during their breeding season, when their energy demand is greatest and when they are most spatially constrained, in order to understand and manage this potential impact on their populations. In the Benguela upwelling region, 2 endemic vulnerable seabirds, Cape gannets Morus capensis and African penguins Spheniscus demersus, mainly eat anchovy Engraulis encrasicolus and sardine Sardinops sagax, both of which are exploited by the purse-seine fishery. A recent eastward displacement of small pelagic fish off the South African coast has reduced fish availability for both birds and fisheries along the west coast. Using GPS-recorders, we studied the foraging dispersal of birds from 8 colonies containing $95 \%$ of the global Cape gannet and $60 \%$ of the global African penguin populations to assess their overlap with fish catches. Despite the fact that bird data were gathered at very fine spatial and temporal scales (meters and hours), and fisheries data were recorded at much coarser spatial and temporal scales (20 km and months), there was clear overlap in areas used. The main foraging areas of both species were located where purse-seine fisheries caught most fish, with most catches occurring during the birds' breeding season. As birds and fisheries also overlap in the size of the targeted prey and the depth of exploitation, our study suggests the potential for intense competition between purse-seine fisheries and decreasing seabird populations in the southern Benguela. Long-term protection of these seabird species requires the inclusion of a suitable ecological buffer when setting fishery quotas, and implementing marine protected areas closed to fishing around key breeding sites and foraging hotspots may improve their breeding success.
\end{abstract}

KEY WORDS: African penguins · Biotelemetry · Cape gannets · Conservation · Industrial fisheries · Offshore reserves $\cdot$ Foraging hotspots

Resale or republication not permitted without written consent of the publisher

\section{INTRODUCTION}

The oceans are one of humanity's most importance resources, and human welfare, economics, and survival are tightly linked with the health of marine eco- systems (Costanza 1999). However, marine ecosystems are deeply altered by humans, to an extent that has long been underestimated (Jackson et al. 2001). The most profound effect is due to exploitive use of marine resources, mainly through fishing (Pauly et al. 1998). 
Industrial-scale fisheries have altered and degraded marine ecosystems (Botsford et al. 1997, Williams 1998, Worm et al. 2006), probably reducing the biomass of fish top predators by an estimated $90 \%$ compared to pre-industrial levels (Myers \& Worm 2003). Many marine top predators (such as pinnipeds, cetaceans, seabirds and sharks) that play an important role in the maintenance of ecosystem function (Myers et al. 2007) are threatened by fishing both through mortality caused by fishing gear (e.g. González-Zevallos \& Yorio 2006) as well as direct competition with fisheries (e.g. Furness \& Tasker 2000). Upwelling systems, such as the Humboldt and the Benguela regions, are waspwaist ecosystems (Cury et al. 2000), largely rely on a species-poor intermediate trophic level dominated by 2 genera of small pelagic fish (sardines Sardinops spp. and anchovies Engraulis spp.) that regulate the transfer of energy from lower to upper trophic levels. In these ecosystems, the breeding success and/or abundance of top predator populations are related to the availability of these small pelagic fish (see Crawford \& Jahnke 1999). Because the populations of such fish fluctuate at large temporal and spatial scales, these top predators have developed life-history traits to buffer against these fluctuations, and thus can show behavioural flexibility. However, fisheries exploitation increases the pace and scale of these fluctuations to a scale of magnitude beyond the range of natural variation, reducing the possibility for predators to accommodate them (Duffy 1983, Crawford 1999).

For instance, in the Benguela upwelling system, overexploitation of sardines Sardinops sagax off South Africa in the 1960s and off Namibia in the 1970s lead to their populations collapsing (Griffiths et al. 2004). Anchovies Engraulis encrasicolus largely replaced sardines in the fisheries landing off South Africa (Cochrane et al. 1998), but small pelagic fish populations off Namibia have still not yet recovered (Griffiths et al. 2004). Consequently, the global population of the endemic Cape gannets Morus capensis and African penguins Spheniscus demersus, which depend upon small pelagic fish (Crawford 1999), decreased by $50 \%$, rendering them vulnerable to extinction (Crawford 1999, IUCN 2006). Off the west coast of South Africa, bird numbers have further decreased since the mid-1990s due to a lack of food (Crawford et al. 2006, Pichegru et al. 2007) associated with recent shifts in the distribution and availability of their prey (van der Lingen et al. 2005, Roy et al. 2007, Grémillet et al. 2008a). It is essential to estimate the spatial and temporal overlap between purse-seine fisheries that target small pelagic fish, and the location and extent of feeding grounds of these birds during the breeding season, in order to understand and manage potential fishery impacts on seabird populations. Food availability during reproduction plays a key role in the population dynamics of highly mobile species (e.g. Lewis et al. 2006), especially during young-rearing when (1) the energetic constraints are strongest upon breeding adults (Stearns 1992) as they need to feed both themselves and their growing offspring, and when (2) they are most spatially constrained.

Because scale is a critical factor in determining resource-use overlap between top predators and fisheries (e.g. Reid et al. 2004), results from studies that attempted to estimate the impact of competition between seabirds and fisheries have often been contradictory (see Tasker et al. 2000 and references therein). Often some overlap can be found at a coarse scale $(>300 \mathrm{~km})$, but not at a fine scale $(<3 \mathrm{~km})$ (e.g. Fauchald et al. 2000). In this analysis, we estimate the overlap between vulnerable seabirds and South African purseseine fishery activities at a spatial scale of $<20 \mathrm{~km}$ and a monthly temporal scale. We used GPS tracking of birds from 8 colonies - containing $95 \%$ of the global Cape gannet (Crawford 2005) and $60 \%$ of the global African penguin populations (Crawford \& Whittington 2005) - to determine their foraging distribution and overlap with spatially explicit data on catches of sardines and anchovies made by the pelagic fishery during the chick-rearing period. Despite the disparate scales of the 2 datasets, with the bird data gathered at very fine spatial and temporal scales (meters and hours), and the fisheries data recorded at coarser spatial and temporal scales (20 km and months), we contend that a significant overlap over such a fine spatial and temporal scale would provide strong evidence for competition. This method would also reveal areas of important conservation value and can help in the design of marine protected areas (MPAs).

\section{MATERIALS AND METHODS}

Bird foraging behaviour: data collection. The foraging behaviour of breeding Cape gannets and African penguins was studied between 2002 and 2007 under permits issued by Cape Nature Conservation and South African National Parks. Cape gannets were studied at all 3 South African colonies: Bird Island (Lambert's Bay,

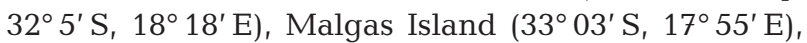

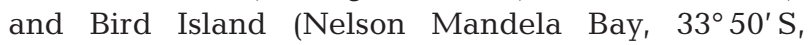
$\left.26^{\circ} 17^{\prime} \mathrm{E}\right)$. African penguins were studied at the 5 largest of the 17 South African sites: Dassen Island $\left(33^{\circ} 25^{\prime} \mathrm{S}, 18^{\circ} 04^{\prime} \mathrm{E}\right)$, Robben Island $\left(33^{\circ} 47^{\prime} \mathrm{S}, 18^{\circ} 22^{\prime} \mathrm{E}\right)$, Boulders Beach $\left(34^{\circ} 12^{\prime} \mathrm{S}, 18^{\circ} 27^{\prime} \mathrm{E}\right)$, Dyer Island $\left(34^{\circ} 40^{\prime} \mathrm{S}, 1^{\circ} 25^{\prime} \mathrm{E}\right)$ and Bird Island (Nelson Mandela Bay) (Fig. 1).

The tracking loggers deployed on the birds have been used on several occasions and are only briefly described here (see details in Grémillet et al. 2004, Ryan et al. 2004). Two types of data loggers were used: (1) GPS 

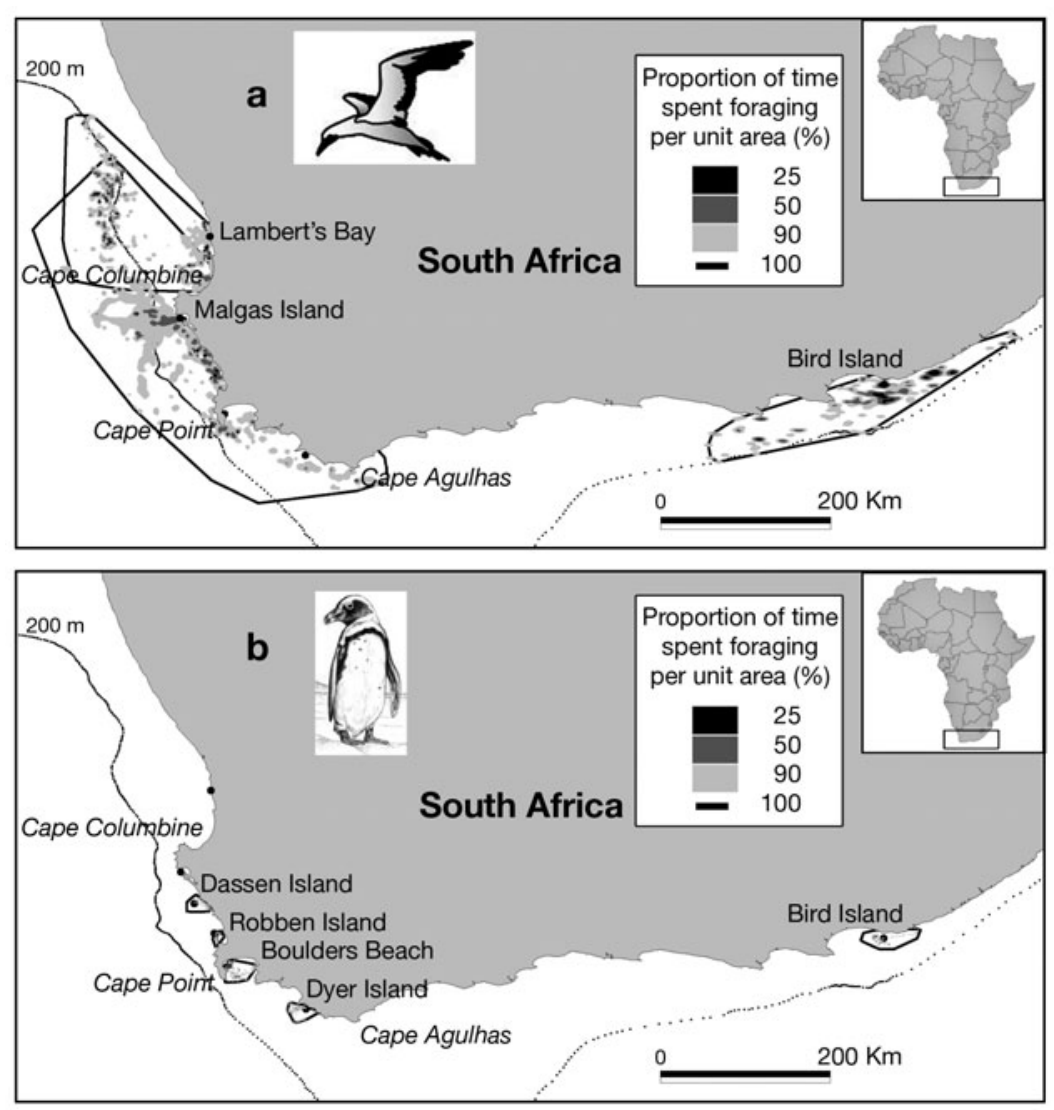

Fig. 1. Foraging grounds (kernels 25, 50,90\% and minimum convex polygon [MCP] $100 \%$ ) of (a) breeding Cape gannets from 3 colonies and (b) African penguins from 5 colonies during 2002 to 2007

data-loggers $(95 \times 48 \times 24 \mathrm{~mm}$; Technosmart $)$, that record latitude and longitude at $10 \mathrm{~s}$ intervals to an accuracy better than $10 \mathrm{~m}$. (2) GPS-TD loggers (a GPS combined with a time-depth recorder; $96 \times 39 \times 26.5 \mathrm{~mm}$; Earth and Ocean Technologies), that record latitude and longitude at $1 \mathrm{~min}$ intervals to an accuracy better than $10 \mathrm{~m}$, and temperature and depth at $1 \mathrm{~s}$ intervals to the nearest $0.1 \mathrm{~m}$. All devices were housed in streamlined fibrecomposite containers and weighed $<2.5 \%$ of both species' adult body mass, which is below the $3 \%$ limit recommended for flying birds (Phillips et al. 2003).

Cape gannets breed a single chick between September and February, whereas African penguins raise a brood of one or 2 chicks between March and August. In both species the parents share the care of their young, with typically one adult attending the nest or burrow when the partner is at sea (Crawford 2005, Crawford \& Whittington 2005). Adult birds rearing small chicks of similar age (average of 3 and 2 wk old for gannets and penguins, respectively) were caught on their nest site. The devices were attached to feathers on their lower back with waterproof tape, allowing minimal damage to the plumage (Wilson et al. 1997).
Handling lasted 4 to 8 min from capture to release and care was taken to minimize the bird's stress (the birds' heads were covered, and those equipped during the day were shaded). After deployment, nest sites with instrumented birds were monitored until the adult returned, allowing it to be recaptured and the logger removed. Previous studies showed no significant difference in the foraging behaviour of experimental and control birds (Petersen et al. 2006, Pichegru et al. 2007), and no apparent impacts have been detected on the welfare of the animals.

Bird foraging behaviour: data analysis. Because African penguins have relatively small foraging ranges (Wilson 1985), their foraging habitat was inferred from their complete GPS tracks. By comparison, Cape gannet often commute over long distances to reach their foraging areas. Therefore, their foraging locations were inferred from their GPS tracks based on the path sinuosity, after Grémillet et al. (2004). For each colony, we defined different core foraging areas, covering their home range (Minimum Convex Polygon [MCP] - $100 \%$ ) and a range of proportional use ranges, based on 3 to $99 \%$ (in $3 \%$ intervals) of the time spent foraging per unit area (kernel analysis, smoothing factor chosen according to the Least Square Cross Validation method, Girard et al. 2002), using Arcview GIS 3.2 (ESRI). When data from more than 1 breeding season were available for a colony, they were pooled. This method takes into account inter-annual variability and birds' maximum foraging range, and it reveals feeding hotspots, giving more statistical weight to areas that are used consistently over several years, which is part of BirdLife criteria to define marine Important Bird Areas (www.birdlife.org).

Fisheries' activities: temporal and spatial distribution. The weight $(\mathrm{t})$ of anchovies and sardines caught per $10 \times 10$ nautical mile $(18.6 \times 18.6 \mathrm{~km})$ grid cell by the South African purse-seine fishery between 2002 and 2007 was obtained from catch data recorded monthly by Marine and Coastal Management (South African Ministry of Environment and Tourism). The purse-seine fishery is active throughout the year (Fairweather et al. 2006). The temporal heterogeneity in fishery catches was tested with a General Linear Model, with the fisheries' catches as an independent factor, and months and years as explanatory variables. 
The analyses were performed on anchovy and sardine catches separately. Spatial heterogeneity in the presence/absence of fish catches over the $6 \mathrm{yr}$ period for the 341 cells overlapping Cape Gannet locations was calculated as follows: for each grid cell we scored the heterogeneity as the count of presences or absences, whichever was lower, so that e.g. $0,0,1,1,0,0$ and $1,1,0,0,1,1$ both score 2 . The overall heterogeneity was expressed as the sum over all the cell scores, this gives values ranging from 0 (perfect similarity) to 1364 (maximum heterogeneity). To test the significance of this statistic, we performed a randomization test by taking 999 random samples with replacement across years. We used the R software for calculations.

Spatial overlap between birds and fisheries. The spatial overlap between fishing activities and birds' foraging behaviour was determined using the $10 \times 10$ nautical mile $(18.6 \times 18.6 \mathrm{~km})$ grid. Each grid cell was associated with an amount of fish catch (if any) and the lowest kernel contour of the birds' foraging range (if the cell was also used by the birds). Thus, we calculated the proportion of the annual average catches of small pelagic fish by the purse-seine fisheries that occurred within the total foraging range of penguins for each colony, and within areas where gannets spent 50,75 and $90 \%$ of their time spent foraging, following BirdLife's criteria for the selection of Important Bird Areas. Although we analyzed the amount of fishing activities in the foraging range of birds from each colony separately, we had to analyze together the areas used by gannets breeding on the colonies from the west coast (Bird Island, Lambert's Bay, and Malgas Island), as their foraging ranges overlapped (Fig. 1). Testing the overlap of fisheries and birds from these 2 colonies separately would lead to an overestimation of the competition between boats and gannets on the west coast.

\section{RESULTS}

Between 2002 and 2007, 166 gannet and 91 penguin foraging tracks were gathered from the 8 breeding colonies (Table 1). Gannet foraging trips lasted almost twice as long as those of penguins and had a mean foraging range $(112 \mathrm{~km})$ an order of magnitude greater than those of penguins $(12.5 \mathrm{~km}$, Table 1$)$. The total foraging area (MCP 100\%) of gannets covered $40176 \mathrm{~km}^{2}$, an area $>10$-fold greater than the total foraging area of the 5 penguin colonies studied $\left(5022 \mathrm{~km}^{2}\right.$, Table 2). The gannets' foraging range also included the locations of all other South African penguin colonies (Crawford \& Whittington 2005). Although both species can show substantial interannual variability in some foraging parameters (trip durations during the same period of the breeding cycle can almost double between colonies and years, see Table 1), core foraging areas of gannets and penguins were located mainly in shallow shelf waters $(<200 \mathrm{~m})$, where most of the annual catch of purse-seine fisheries

Table 1. Morus capensis and Spheniscus demersus. Average trip duration, foraging path length and foraging range of Cape gannets and African penguins from 8 colonies and 6 years in South Africa (values are mean \pm SD). Track numbers in parentheses are incomplete tracks from which no foraging parameters could be extracted but which were included in the spatial analyses

\begin{tabular}{|c|c|c|c|c|c|}
\hline Colony & Year & $\mathrm{N}$ (tracks) & Trip duration (h) & Path length (km) & Foraging range $(\mathrm{km})$ \\
\hline \multicolumn{6}{|l|}{ Cape gannets } \\
\hline Bird Island, Lambert's Bay & $\begin{array}{l}2002 \\
2003\end{array}$ & $\begin{array}{l}41 \\
30\end{array}$ & $\begin{array}{l}13.1 \pm 8.8 \\
20.0 \pm 9.3\end{array}$ & $\begin{array}{l}244.6 \pm 126.1 \\
434.1 \pm 166.2\end{array}$ & $\begin{array}{r}68.2 \pm 39.0 \\
132.2 \pm 45.3\end{array}$ \\
\hline Malgas & $\begin{array}{l}2002 \\
2003 \\
2004 \\
2005 \\
2006\end{array}$ & $\begin{array}{l}26 \\
20 \\
14 \\
36 \\
43\end{array}$ & $\begin{array}{l}23.1 \pm 9.7 \\
18.3 \pm 13.1 \\
31.3 \pm 14.1 \\
29.1 \pm 12.7 \\
22.8 \pm 11.1\end{array}$ & $\begin{array}{l}368.6 \pm 200.2 \\
412.7 \pm 323.1 \\
476.9 \pm 199.5 \\
514.4 \pm 234.8 \\
397.6 \pm 199.6\end{array}$ & $\begin{array}{l}105.8 \pm 59.0 \\
114.5 \pm 82.7 \\
122.8 \pm 55.9 \\
132.6 \pm 62.7 \\
104.0 \pm 55.7\end{array}$ \\
\hline Bird Island, Nelson Mandela Bay & 2005 & 27 & $13.8 \pm 7.2$ & $367.0 \pm 232.0$ & $112 \pm 89$ \\
\hline Total & & 166 & $21.4 \pm 6.5$ & $402.0 \pm 81.5$ & $111.5 \pm 20.6$ \\
\hline \multicolumn{6}{|l|}{ African penguins } \\
\hline Dassen Island & $\begin{array}{l}2003 \\
2004\end{array}$ & $\begin{array}{c}3(4) \\
28\end{array}$ & $\begin{array}{r}9.2 \pm 1.3 \\
11.3 \pm 4.7\end{array}$ & $\begin{array}{l}33.6 \pm 2.7 \\
33.5 \pm 2.5\end{array}$ & $\begin{array}{r}10.1 \pm 0.9 \\
5.6 \pm 1.2\end{array}$ \\
\hline Robben Island & 2003 & $7(11)$ & $11.1 \pm 2.0$ & $34.4 \pm 7.7$ & $9.5 \pm 3.7$ \\
\hline Boulders Beach & $\begin{array}{l}2003 \\
2007\end{array}$ & $\begin{array}{c}10(12) \\
9\end{array}$ & $\begin{array}{l}14.4 \pm 4.0 \\
10.2 \pm 1.8\end{array}$ & $\begin{array}{l}46.5 \pm 13.3 \\
25.1 \pm 2.6\end{array}$ & $\begin{array}{r}19.3 \pm 6.2 \\
9.7 \pm 2.4\end{array}$ \\
\hline Dyer Island & 2007 & 12 & $14.0 \pm 7.6$ & $46.8 \pm 18$ & $15.76 \pm 4.0$ \\
\hline Bird Island, Nelson Mandela Bay & 2007 & 15 & $21.8 \pm 5.2$ & $57.8 \pm 17$ & $17.1 \pm 11.2$ \\
\hline Total & & 91 & $13.1 \pm 4.2$ & $39.7 \pm 11.1$ & $12.5 \pm 5.0$ \\
\hline
\end{tabular}


is also taken (Fig. 2). An annual average of 222000 tons of anchovies and 255000 tons of sardines were caught by the pelagic fishery over the period 2002 to 2007 all along the South African coast. Almost all anchovy catches occurred on the west coast (Fig. 2), where most of the seabird colonies are also located.

\section{Temporal overlap}

Small pelagic catches by purse-seine fisheries fluctuated over time between 2002 and 2007. Sardine catches varied significantly between months $(F=4.95$, $\mathrm{df}=11, \mathrm{p}<0.01)$ and years $(F=5.92, \mathrm{df}=5, \mathrm{p}<0.001)$, with a sharp decrease from 2004 onward, from $374000 \mathrm{t}$ in 2004 down to $140000 \mathrm{t}$ in 2007 . The peak of sardine catches on the west coast occurred between September and March (although the catches in December were low, Fig. 3), which coincides with the timing of the Cape gannet breeding season (Crawford 2005). Anchovy catches remained constant over the years $(F=1.68, \mathrm{df}=5, \mathrm{p}=0.155)$, but varied significantly between months $(F=11.61, \mathrm{df}=11, \mathrm{p}<0.001)$, peaking in the austral autumn (Fig. 3), which is also peak breeding season for African penguins (Crawford \& Whittington 2005). Although there are no anchovy catches on the east coast (Fig. 3), anchovies are caught as by-catch in sardine fisheries (Fairweather et al. 2006), and sardine fishing peaks on the east coast also during the austral autumn.

\section{Spatial overlap}

The overall heterogeneity score obtained for the purse-seine fishing overlapping Cape gannet locations was 224 ; this lies within the $95 \%$ confidence interval (125 to 278) calculated by the randomization test, indicating that spatial differences between years in presence/absence of fishing do not differ from a random process. Purse-seine fishing boats thus exploited consistently the same zones over the years of our study.

Although penguins show a restricted foraging range (Tables 1 \& 2, Fig. 1), their colonies are located in areas of important concentrations of fishery catches (Figs. $1 \& 2$, Table 2). The entire foraging range of the 5 colonies covered only $3.7 \%$ of the entire marine area exploited by purse-seine fisheries. Yet, fisheries caught $14.2 \%$ of their average annual catches in this small area (Table 2). Also, different colonies endured different intensities of competition. For instance, fishing boats took $6 \%$ of their annual catches in the foraging range of penguins from Dassen and Robben Islands on the west coast, the surface of which represents less than $1 \%$ of the total industrial fishing area (Table 2). Similarly, fisheries were catching the same amount of pelagic fish in the foraging area of the single colony of Dyer Island (Table 2), the eastern most colony of the west coast (Fig. 1).

Although the area where gannets spent $90 \%$ of their foraging time was almost 10 -fold larger than the penguins' entire foraging range, fisheries caught only

Table 2. Morus capensis and Spheniscus demersus. Foraging area of Cape gannets and African penguins (50, 75, 90\% kernel contours for gannets, minimum convex polygon [MCP] $100 \%$ for penguins) for each studied colony, proportion of these respective areas of the total area exploited by purse-seine fisheries, and proportion of average annual catches of small pelagic fish by purseseine fisheries taken from these different areas. Proportion of global population supported by each studied colony is also given

\begin{tabular}{|c|c|c|c|c|c|}
\hline Colony & $\begin{array}{c}\text { Proportion of } \\
\text { global population } \\
(\%)\end{array}$ & $\begin{array}{c}\text { Kernel } \\
\text { or MCP } \\
(\%)\end{array}$ & $\begin{array}{c}\text { Foraging area } \\
\qquad\left(\mathrm{km}^{2}\right)\end{array}$ & $\begin{array}{l}\text { Proportion of size of } \\
\text { foraging area vs. } \\
\text { total fisheries area }(\%)\end{array}$ & $\begin{array}{c}\text { Proportion of fisheries' } \\
\text { catch within } \\
\text { foraging range }(\%)\end{array}$ \\
\hline \multicolumn{6}{|l|}{ Cape gannets } \\
\hline West coast (Bird Island & 27.4 & 50 & 10602 & 7.8 & 11.3 \\
\hline \multirow[t]{2}{*}{ [Lamberts Bay], Malgas Island) } & & 75 & 19716 & 14.4 & 17.2 \\
\hline & & 90 & 28644 & 21.0 & 27.5 \\
\hline \multirow[t]{3}{*}{ Bird Island (Nelson Mandela Bay) } & 65.6 & 50 & 5022 & 3.7 & 0.7 \\
\hline & & 75 & 9672 & 7.1 & 1.4 \\
\hline & & 90 & 11532 & 8.4 & 1.5 \\
\hline Total & 93 & & 40176 & 29.4 & 29.0 \\
\hline \multicolumn{6}{|l|}{ African penguins } \\
\hline Dassen Island & 36.7 & 100 & 558 & 0.4 & 3.3 \\
\hline Robben Island & 10.2 & 100 & 744 & 0.5 & 2.8 \\
\hline Boulders Beach & 3.0 & 100 & 1116 & 0.8 & 1.9 \\
\hline Dyer Island & 5.7 & 100 & 1116 & 0.8 & 6.1 \\
\hline Bird Island (Nelson Mandela Bay) & 7.8 & 100 & 1488 & 1.1 & 0.1 \\
\hline Total & 63.4 & & 5022 & 3.6 & 14.2 \\
\hline
\end{tabular}




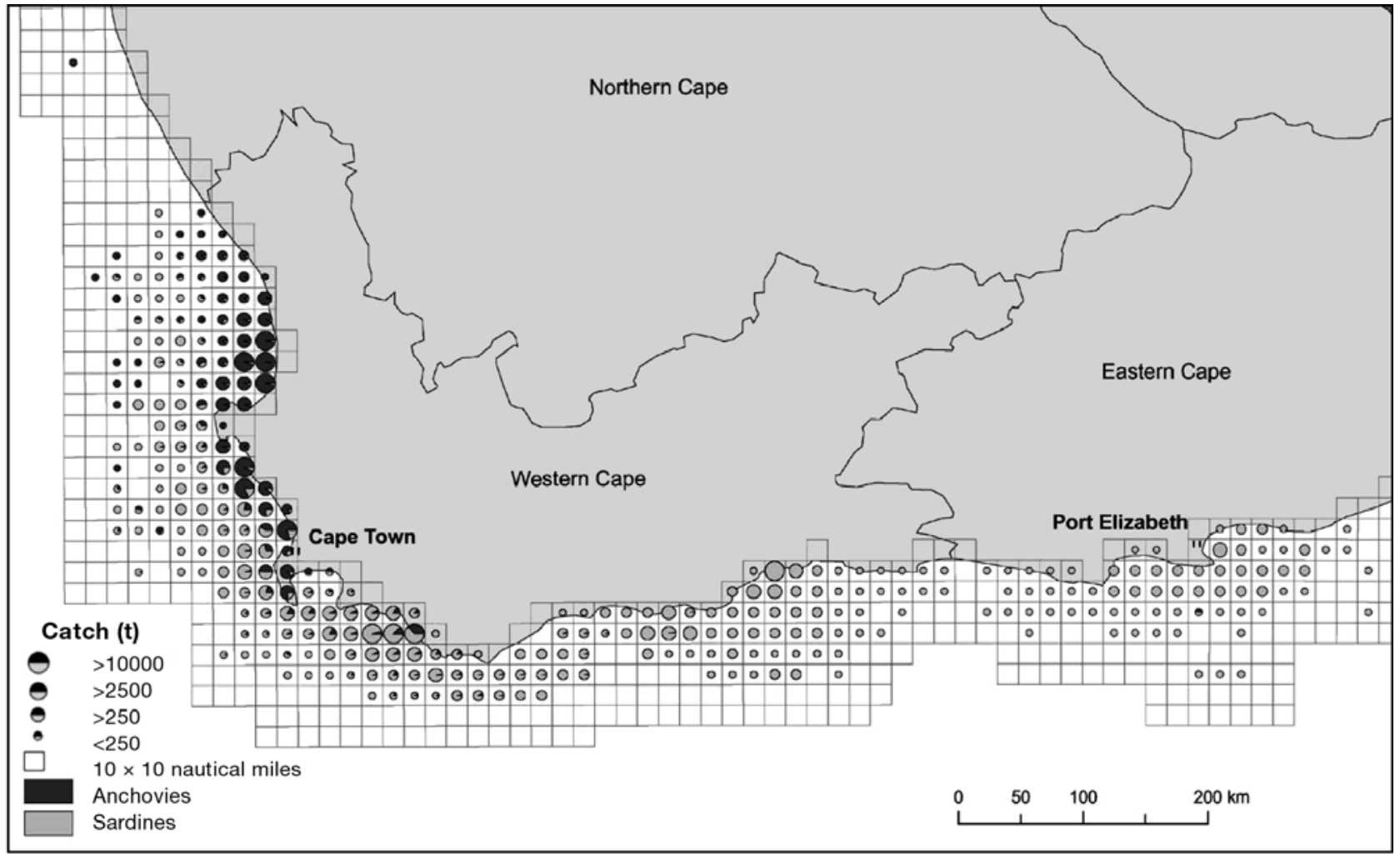

Fig. 2. Engraulis encrasicolus and Sardinops sagax. Average annual catch (in tons) of anchovies and sardines per $10 \times 10$ nautical mile $(18.6 \times 18.6 \mathrm{~km})$ block off South Africa by the purse-seine fishing industry averaged for the period 2002 to 2007 (courtesy of H. Bohbot, CEFE-CNRS Montpellier)
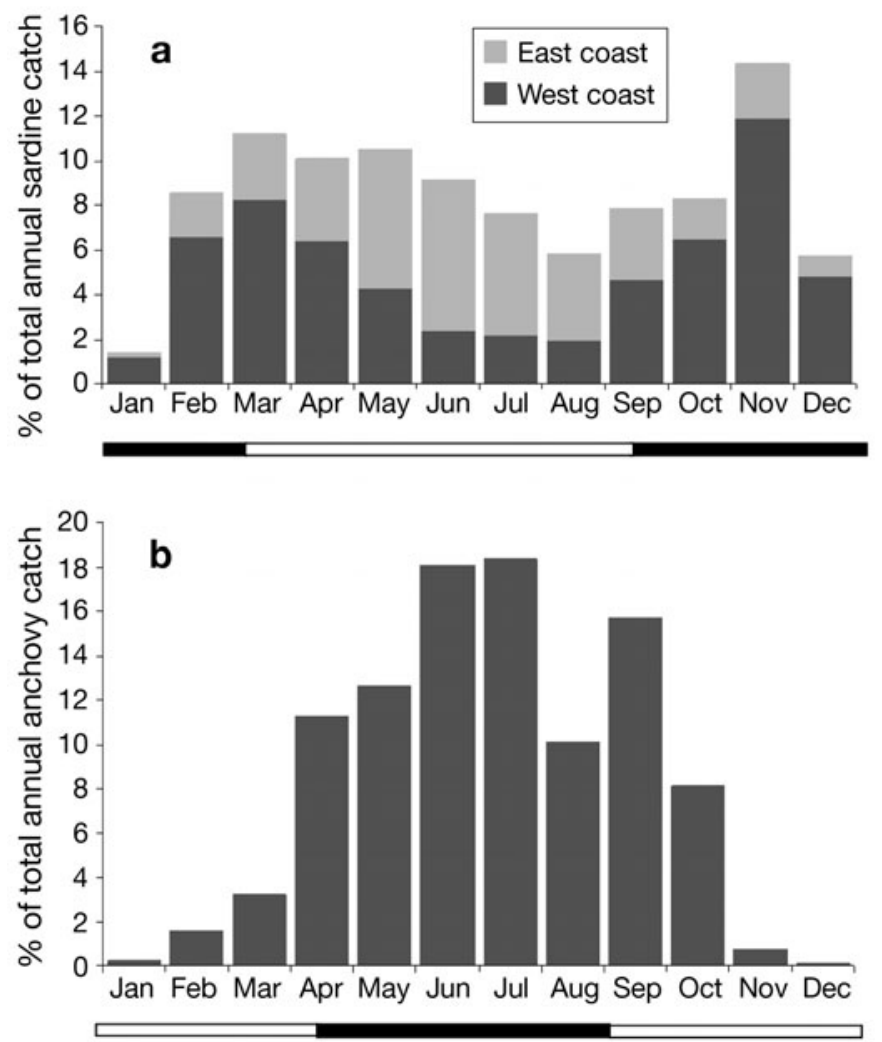

twice as many fish as they caught in the penguin foraging area (Table 2). However, the competition between gannets and fisheries was much stronger on the west coast. Gannets breeding on Bird (Lambert's Bay) and Malgas Islands, showed a foraging range twice as large as that of birds breeding on Bird Island (Nelson Mandela Bay) (Fig. 1, Tables \& 2), within which fishing pressure was almost 20 times greater than it was in the foraging area of the birds from the south coast, in Nelson Mandela Bay (Table 2). Gannets breeding on Bird (Lambert's Bay) and Malgas Islands also exhibited a greater foraging effort, with longer foraging trip durations and foraging path lengths, despite the fact that their population was half the size of that from Bird Island (Nelson Mandela Bay) (Tables 1 \& 2 this study, Pichegru et al. 2007).

Fig. 3. Sardinops sagax and Engraulis encrasicolus. Monthly proportions of the average annual catch of (a) sardine and (b) anchovy west of Cape Agulhas (west coast) and east of Cape Agulhas (east coast) during (a) gannet and (b) penguin breeding (horizontal black bars) and non-breeding (horizontal white bars) seasons for the period of 2002 to 2007 


\section{DISCUSSION}

Our study shows a strong spatio-temporal overlap between seabirds and fisheries targeting small pelagic fish. Purse-seine fisheries caught most of their catches from the core foraging areas of both species of birds (Figs. $1 \& 2$, Table 2). The peak of their catches also occurred during the birds' breeding period (Fig. 3), when the food demands of these marine predators are highest (Stearns 1992). Although interpretation of the data is complicated by the different scales of analysis used between birds and fisheries, there was a clear disproportionate overlap in the areas used.

Both birds and fisheries target prey of the same size. Gannets and penguins target fish of an average length of $\sim 15 \pm 6 \mathrm{~cm}$ (Batchelor \& Ross 1984, Klages et al. 1992, Crawford \& Dyer 1995), whereas the size of the fish caught by fisheries is between 5 and $20 \mathrm{~cm}$ for sardines and 6 and $12 \mathrm{~cm}$ for anchovies (Fairweather et al. 2006). African penguins may reduce competition by targeting smaller, diffuse schools of fish, whereas the fishery targets large aggregations (Wilson 1985). However, both dense and diffuse schools probably form part of the same stock (Duffy \& Wissel 1988). Finally, both birds and fisheries overlap in the depth at which they exploit their prey, as gannets do not dive deeper than 30 m (Ropert-Coudert et al. 2004), and most penguin dives occur between 10 and $70 \mathrm{~m}$ (Wilson 1985, Petersen et al. 2006). Purse-seine fisheries seldom operate at a depth $>50 \mathrm{~m}$ (Armstrong \& Thomas 1989).

Our results illustrate the interactions between birds and fisheries during the whole life cycle of the birds. Indeed, competition between the 2 during the non-breeding period has been implicated in the decline in African penguins off South Africa (Burger \& Cooper 1984) at that time. Overlap with fisheries activities during postnatal dispersion can also be crucial in juvenile survival (Weimerskirch et al. 2006) and immature African penguins showed a very low survival in areas open to fishing, compared to those in areas closed to fisheries (Duffy et al. 1984), probably due to the combined threats of bycatch and competition over the same prey. Although some fisheries can provide food for some seabirds through their wastes (e.g. Tasker et al. 2000), African penguins do not feed on fishery offal, as no fishery waste has ever been found in their diet samples (Marine and Coastal Management unpubl. data). Cape gannets from the west coast colonies can make extensive use of wastes from a demersal fishery (Berruti et al. 1993, Pichegru et al. 2007); however, their chick survival on such a diet is extremely low (Grémillet et al. 2008b). Therefore, gannets do not benefit from these fisheries in terms of reproductive output. Finally, purse-seine fisheries do not process their catches on board, so their waste production is minimal (N. Okes, WWF, pers. comm.).
The recent eastward shift in the distribution of both anchovy and sardine off the South African coast has further reduced fish availability along the west coast and the sardine population has also decreased substantially in recent years (van der Lingen et al. 2006), which is reflected in this study by the sharp decrease in sardine catches between 2004 and 2007. The direct competition between birds and fisheries demonstrated by our data, particularly on the west coast (Figs. $1 \& 2$, Table 2), is probably increased during prey scarcity to the detriment of the birds, thus weighing heavily on already vulnerable species. African penguin and Cape gannet populations may soon be re-classified as Endangered (Kemper et al. 2007), probably due to lack of food (Crawford et al. 2006, Pichegru et al. 2007), and conservation measures are urgently required.

A first step is to integrate the birds' needs into an Ecosystem Approach to Fisheries (EAF; Shannon et al. 2006). An EAF for the pelagic fishery is being developed by the Marine and Coastal Management, the regulatory authority for South Africa's marine fisheries. One aspect of this EAF is a consideration of the amount of small pelagic fish needed by penguin populations in order to survive and breed successfully, and incorporation of this consideration into the Operational Management Procedure (OMP) used to set the annual Total Allowable Catch (TAC) for the pelagic fisheries. However, further measures may be necessary, and although progress has been achieved establishing a number of MPAs in South Africa ${ }^{1}$, the marine area that is currently protected (1.6\% of the Exclusive Economic Zone of South Africa) is still far from the $10 \%$ goal set by the United Nations Convention on Biodiversity. Studies such as the present one provide crucial information in revealing biological hotspots under environmental pressure, and suggesting zones that should be protected as a priority. Cape gannets and African penguins forage in offshore environments (deeper than $30 \mathrm{~m}$ ) while breeding, and these environments are poorly protected (Game et al. 2009), even though they play a central role in the stability and resilience of ecosystems as top predators (e.g. Myers et al. 2007). Moreover, top predators benefit from an ecologically justified charisma (Sergio et al. 2006), which can help in raising funds and finding support in the public and stakeholders. As such, the African penguin is a 'flagship' and an economically valuable species (Crawford 2005). Offshore MPAs for pelagic predators are needed to preserve ecosystem resilience and stability (Hyrenbach et al. 2000, Worm et al. 2006, Game et al. 2009), but a crucial issue regarding their establishment is to determine their boundaries in a dynamic environment.

\footnotetext{
${ }^{1}$ Lemm \& Attwood (2003) State of marine protected area
} management in South Africa. Unpublished report, WWF 
In many instances, indices of marine primary productivity and abiotic features such as bathymetry are used to define seabird MPAs (Louzao et al. 2006). However, the most important guide for defining the boundaries of such MPAs is the prey field utilised by the birds (Hooker \& Gerber 2004). Our study is one of the first to bypass proxies of marine productivity, and to link seabird foraging hotspots directly with the spatio-temporal abundance of their prey, as well as fishing activities sharing this resource (Grémillet et al. 2008a).

From our results, we recommend protecting areas that include the foraging range of penguins breeding on Dassen, Robben and Dyer Island colonies. Indeed, such areas fulfil criteria for marine Important Bird Areas as defined by BirdLife International (www. birdlife.org). African penguin numbers have decreased dramatically in recent years (by $50 \%$ between 2004 and 2006, Crawford et al. 2008), threatening this species with rapid extinction. The areas delimited by our study birds were used consistently over several breeding seasons, thus representing important pelagic feeding grounds for African penguins. These areas were also exploited by other species, such as Cape gannets (as shown in this study) and Cape cormorants Phalacrocorax capensis (M. Hamann et al. unpubl. data). These 3 seabird species have a restricted distribution, and are all endemic to Southern Africa. Therefore, African penguins, even though showing a small foraging range compared to other seabird species, act as an umbrella species (Roberge \& Angelstam 2004), and protecting their foraging habitats will benefit large sections of the southern Benguela upwelling ecosystem.

The concept of area closures certainly warrants further exploration (Hooker 2006), particularly for spatially constrained predators such as African penguins that depend on a reliable prey base within a short commuting distance of their breeding islands while feeding chicks. Closure to purse-seine fishing of an area of $20 \mathrm{~km}$ radius around Dassen Island (see Fig. 1) has been implemented for 2008 and 2009 by Marine and Coastal Management, as part of an experiment to test whether such closure improves penguin reproductive success compared to an adjacent colony on Robben Island, which will not be closed to fishing ${ }^{2}$. This assumes that limited closures will enhance fish availability locally, despite large-scale movements by pelagic

\footnotetext{
${ }^{2}$ Marine and Coastal Management (South Africa) (2007) Recommendation from the Ecosystem Approach to Fisheries and Pelagic Scientific Working Groups re proposed feasibility study to inform the design of an experiment to determine the effects of closure to purse-seine fishing of areas around penguin breeding colonies. Unpublished Document EAFWG/OCT2007/STG/07. Marine and Coastal Management, Cape Town
}

fish (Roy et al. 2007). Ideally, MPAs for highly mobile seabirds should have flexible boundaries (Hyrenbach et al. 2000), with limited catches in these areas. By monitoring the foraging behaviour and reproductive output of predators before and after the formation of an MPA, it is possible to test its efficacy as a conservation tool. Foraging behaviour is at the interface between population dynamics and the environment within which populations evolve, since any changes in the environment will affect the foraging behaviour of predators before they affect their life history traits (Hamer et al. 2006). Coupled with energetic modelling, GPS monitoring thus provides a rapid and powerful index of population health and trends (Grémillet et al. 2006, Pichegru et al. 2007) and can be used as a relevant tool in conservation management.

Acknowledgements. This study was funded by the Centre National de la Recherche Scientifique via an ACI jeunes chercheuses et jeunes chercheurs to D.G. and by the DEPE-IPHCCNRS. L.P. was funded by a studentship of the French Ministry of Research. We thank the South African National Parks, with particular regards to A. Padayachee, J. Simon and M. Kuun, as well as Cape Nature Conservation, in particular L. Waller and P. Michels. Many people gave crucial help on this study, either logistically (L. Edwards, J. Campbell, W. Chivell, O. Koos) or scientifically (C. Attwood, F. Bonadonna, L. Underhill, C. Loiseau, A. Schmidt). We warmly thank them all.

\section{LITERATURE CITED}

Armstrong MJ, Thomas RM (1989) Clupeoids. In: Payne AIL, Crawford RJM (eds) Oceans of life off southern Africa. Vlaeberg Publishers, Halfway House, p 105-121

Batchelor AL, Ross GJB (1984) The diet and implications of dietary change of Cape gannets on Bird Island, Nelson Mandela Bay. Ostrich 55:45-63

Berruti A, Underhill LG, Shelton PA, Moloney CL, Crawford RJM (1993) Seasonal and interannual variation in the diet of two colonies of the Cape gannet (Morus capensis) between 1977-78 and 1989. Colon Waterbirds 16:158-175

Botsford LW, Castilla JC, Peterson CH (1997) The management of fisheries and marine ecosystem. Science 277: 509-515

Burger AE, Cooper J (1984) The effects of fisheries on seabirds in South Africa and Namibia. In: Nettleship DN, Sanger GA, Springer PF (eds) Marine birds: their feeding ecology and commercial fisheries relationships. Special publication, Canadian Wildlife Service, Ottawa, p 150-160

> Cochrane KL, Butterworth DS, de Oliveira JAA, Roel BA (1998) Management procedures in a fishery based on highly variable stocks and with conflicting objectives: experiences in the South African pelagic fishery. Rev Fish Biol Fish 8:177-214

Costanza R (1999) The ecological, economic, and social importance of the oceans. Ecol Econ 31:199-213

Crawford RJM (1999) Seabird responses to long-term changes of prey resources off southern Africa. In: Adams NJ, Slotow RH (eds) Proceedings of the 22nd International Ornithological Congress, Durban. BirdLife South Africa, Johannesburg, p 688-705

Crawford RJM (2005) Cape Gannet. In: Hockey PAR, Dean 
WRJ, Ryan PG (eds) Roberts' birds of southern Africa, 7th edn. John Voelcker Bird Book Fund, Cape Town, p 565-567

> Crawford RJM, Dyer BM (1995) Responses by four seabirds to a fluctuating availability of Cape Anchovy Engraulis capensis off South Africa. Ibis 137:329-339

Crawford RJM, Jahnke J (1999) Comparison of trends in abundance of guano-producing seabirds in Peru and southern Africa. S Afr J Mar Sci 21:145-156

Crawford RJM, Whittington PA (2005) African penguin. In: Hockey PAR, Dean WRJ, Ryan PG (eds) Roberts' birds of southern Africa, 7th edn. John Voelcker Bird Book Fund, Cape Town, p 631-634

> Crawford RJM, Barham PJ, Underhill LG, Shannon LJ and others (2006) The influence of food availability on breeding success of African penguins Spheniscus demersus at Robben Island, South Africa. Biol Conserv 132:119-125

Crawford RJM, Underhill LG, Coetzee JC, Fairweather T, Shannon LJ, Wolfaardt AC (2008) Influences of the abundance and distribution of prey on African penguins Spheniscus demersus off western South Africa. Afr J Mar Sci 30:167-175

> Cury P, Bakun A, Crawford RJM, Jarre A, Quinones RA, Shannon LJ, Verheye HM (2000) Small pelagics in upwelling systems: patterns of interaction and structural changes in 'wasp-waist' ecosystems. ICES J Mar Sci 57:603-618

Duffy DC (1983) Environmental uncertainty and commercial fishing: effects on Peruvian guano birds. Biol Conserv 26: 227-238

Duffy DC, Wissel C (1988) Models of fish school size in relation to environmental productivity. Ecol Model 40: 201-211

Duffy DC, Hays C, Plenge MA (1984) The conservation status of Peruvian seabirds. In: Croxall JP, Evans PGH, Schreiber RW (eds) Status and conservation of the World's seabirds. Technical publication No 2, International Council for Bird Preservation, Cambridge, p 245-259

Fairweather TP, van der Lingen CD, Booth AJ, Drapeau L, van der Westhuizen JJ (2006) Indicators of sustainable fishing for South African sardine Sardinops sagax and anchovy Engraulis encrasicolus. Afr J Mar Sci 28:661-680

Fauchald P, Erikstad KE, Skarsfjord H (2000) Scale-dependent predator-prey interactions: the hierarchical spatial distribution of seabirds and prey. Ecology 81:773-783

Furness RW, Tasker ML (2000) Seabird-fishery interactions: quantifying the sensitivity of seabirds to reductions in sandeel abundance, and identification of key areas for sensitive seabirds in the North Sea. Mar Ecol Prog Ser 202: 253-264

Game ET, Grantham HS, Hobday AJ, Pressey RL and others (2009) Pelagic protected areas: the missing dimension in ocean conservation. Trends Ecol Evol 24:360-369

> Girard I, Ouellet JP, Courtois R, Dussault C, Breton L (2002) Effects of sampling effort based on GPS telemetry on home-range size estimations. J Wildl Manag 66: $1290-1300$

> González-Zevallos D, Yorio P (2006) Seabird use of discards and incidental captures at the Argentine hake trawl fishery in the Golfo San Jorge, Argentina. Mar Ecol Prog Ser 316:175-183

> Grémillet D, Dell'Omo G, Ryan PG, Peters G, Ropert-Coudert Y, Weeks S (2004) Offshore diplomacy, or how seabirds mitigate intra-specific competition: a case study based on GPS tracking of cape gannets from neighbouring colonies. Mar Ecol Prog Ser 268:265-279

> Grémillet D, Pichegru L, Siorat F, Georges JY (2006) Conservation implications of the apparent mismatch between population dynamics and foraging effort in Northern gannets from the English Channel. Mar Ecol Prog Ser 319: $15-25$

> Grémillet D, Lewis S, Drapeau L, van der Lingen CD and others (2008a) Spatial match-mismatch in the Benguela upwelling zone: should we expect chlorophyll and SST to predict marine predator distributions? J Appl Ecol 45: $610-621$

Grémillet D, Pichegru L, Kuntz G, Woakes AJ, Wilkinson S, Crawford RJM, Ryan PG (2008b) A junk food hypothesis for gannets feeding on fishery waste. Proc R Soc Lond B Biol Sci 18:1-9

Griffiths CL, van Sittert L, Best PB, Brown AC and others (2004) Impacts of human activities on marine life in the Benguela: a historical overview. Oceanogr Mar Biol Annu Rev 42:303-392

Hamer KC, Lewis S, Wanless S, Phillips RA and others (2006) Use of gannets to monitor prey availability in the northeast Atlantic Ocean: colony size, diet and foraging behaviour. In: Boyd IL, Wanless S, Camphuysen CJ (eds) Top predators in marine ecosystems. Symposium of the Zoological Society London, Cambridge University Press, Cambridge, p 236-248

Hooker SK (2006) Marine reserves and higher predators. In: Boyd IL, Wanless S, Camphuysen CJ (eds) Top predators in marine ecosystems. Symposium of the Zoological Society London, Cambridge University Press, Cambridge, p 347-360

> Hooker SK, Gerber LR (2004) Marine reserves as a tool for ecosystem-based management: the potential importance of megafauna. Bioscience 54:27-39

> Hyrenbach KD, Forney KA, Dayton PK (2000) Marine protected areas and ocean basin management. Aquat Conserv: Mar Freshwat Ecosyst 10:437-458

IUCN 2006. 2006 IUCN Red List of threatened species. www.iucnredlist.org/

Jackson JBC, Kirby MX, Berger WH, Bjorndal KA and others (2001) Historical overfishing and the recent collapse of coastal ecosystems. Science 293:629-638

Kemper J, Underhill LG, Crawford RJM, Kirkman SP (2007) Revision of the conservation status of seabirds and seals breeding in the Benguela Ecosystem. In: Kirkman SP (ed) Final report of the BCLME (Benguela Current Large Marine Ecosystem) project on top predators as biological indicators of ecosystem change in the BCLME. Avian Demography Unit, Cape Town, p 325-342

Klages NTW, Willis AB, Ross GJB (1992) Variability in the diet of the Cape gannet at Bird Island, Nelson Mandela Bay, South Africa. S Afr J Mar Sci 12:761-771

Lewis S, Grémillet D, Daunt F, Ryan PG, Crawford RJM, Wanless S (2006) Using behavioural variables to identify proximate causes of population change in a seabird. Oecologia 147:606-614

Louzao M, Hyrenbach KD, Arcos MJ, Abello P, de Sola LG, Oro D (2006) Oceanographic habitat of an endangered Mediterranean procellariiform: implications for marine protected areas. Ecol Appl 16:683-1695

Myers RA, Worm B (2003) Rapid worldwide depletion of predatory fish communities. Nature 423:280-283

Myers RA, Baum JK, Shepherd TD, Powers SP, Peterson CH (2007) Cascading effects of the loss of apex predatory sharks from a coastal ocean. Science 315:1846-1850

Pauly D, Christensen V, Dalsgaard J, Froese R, Torres FJ (1998) Fishing down marine food webs. Science 279: 860-863

Petersen SL, Ryan PG, Grémillet D (2006) Is food availability limiting African penguins at Boulders? A comparison of 
foraging effort at mainland and island colonies. Ibis 148: $14-26$

Phillips RA, Xavier JC, Croxall JP (2003) Effects of satellite transmitters on albatrosses and petrels. Auk 120: 1082-1090

Pichegru L, Ryan PG, van der Lingen CD, Coetzee J, RopertCoudert Y, Grémillet D (2007) Foraging behaviour and energetics of Cape gannets Morus capensis feeding on live prey and fishery discards in the Benguela upwelling system. Mar Ecol Prog Ser 350:127-136

Reid K, Sims M, White RW, Gillon KW (2004) Spatial distribution of predator/prey interactions in the Scotia Sea: implications for measuring predator/fisheries overlap. DeepSea Res II 51:1383-1396

Roberge JM, Angelstam P (2004) Usefulness of the umbrella species concept as a conservation tool. Conserv Biol 18: $76-85$

Ropert-Coudert Y, Grémillet D, Ryan PG, Kato A, Naito Y, Le Maho Y (2004) Between air and water: the plunge dive of the Cape Gannet Morus capensis. Ibis 146:281-290

Roy C, van der Lingen CD, Coetzee JC, Lutjeharms JRE (2007) Abrupt environmental shift associated with changes in the distribution of anchovy spawners in the southern Benguela. Afr J Mar Sci 29:309-319

Ryan PG, Petersen S, Peters G, Grémillet D (2004) GPS tracking a marine predator: the effects of precision, resolution and sampling rate on foraging tracks of African penguins. Mar Biol 145:215-223

Sergio F, Newton I, Marchesi L, Pedrini P (2006) Ecologically justified charisma: preservation of top predators delivers biodiversity conservation. J Appl Ecol 43:1049-1055

Shannon LJ, Cury PM, Nel D, van der Lingen CD and others (2006) How can science contribute to an ecosystem ap-

Editorial responsibility: Scott Shaffer,

Santa Cruz, California, USA proach to pelagic, demersal and rock lobster fisheries in South Africa? Afr J Mar Sci 28:115-157

Stearns SC (1992) The evolution of life histories. Oxford University Press, Oxford.

- Tasker ML, Camphuysen CJK, Cooper J, Garthe S, Montevecchi WA, Blaber SJM (2000) The impact of fishing on marine birds. ICES J Mar Sci 57:531-547

van der Lingen CD, Coetzee JC, Demarcq H, Drapeau L, Fairweather TP, Hutchings L (2005) An eastward shift in the distribution of the southern Benguela sardine. GLOBEC Int Newsl 11:17-22

van der Lingen CD, Shannon LJ, Cury P, Kreiner A, Moloney CL, Roux JP, Vaz-Velo F (2006) Resource and ecosystem variability, including regime shifts, in the Benguela Current system. In: Shannon V, Hempel G, Malanotte-Rizzoli P, Moloney C, Woods J (eds) Benguela: predicting a large marine ecosystem. Large Marine Ecosystems 14, Elsevier, Amsterdam, p 147-185

Weimerskirch H, Åkesson S, Pinaud D (2006) Postnatal dispersal of wandering albatross Diomedea exulans: implications for the conservation of the species. J Avian Biol 37: $23-28$

Williams N (1998) Overfishing disrupts entire ecosystems. Science 279:809

Wilson RP (1985) The jackass penguin (Spheniscus demersus) as a pelagic predator. Mar Ecol Prog Ser 25:219-227

Wilson RP, Pütz K, Peters G, Culik BM, Scolaro JA, Charassin JB, Ropert-Coudert Y (1997) Long-term attachment of transmitting and recording devices to penguins and others seabirds. Wildl Soc Bull 25:101-106

- Worm B, Barbier EB, Beaumont N, Duffy JE and others (2006) Impacts of biodiversity loss on ocean ecosystem services. Science 314:787-790

Submitted: November 25, 2008; Accepted: August 28, 2009

Proofs received from author(s): September 13, 2009 